\title{
Social Entrepreneurship Model Based on Quadruple Helix Collaboration: Economic Empowerment in Disabilities Community
}

\author{
Hendrati Dwi Mulyaningsih ${ }^{1,2}$ \\ ${ }^{1}$ Faculty of Economics and Business Universitas Islam Bandung, Indonesia \\ ${ }^{2}$ Research Synergy Foundation
}

\begin{abstract}
Social entrepreneurship is a process of continuous innovation in classifying different social problems to overcome social problems and meet social needs. The social entrepreneurship approach is very promising in creating new opportunities for individuals with disabilities in the emerging industry. The conceptual contribution to developing a theory that explains the relationship between constructions has been less underlined. Thus, this study aims to identify different models and how they work and propose a conceptual model of social entrepreneurship to empower the economy in disability communities. This study uses descriptive analysis by conducting various literature syntheses to understand the contribution of entrepreneurship in social development. Based on discussion and analysis, new model propositions consider the value of co-creation stakeholders and supporting ecosystems such as academics, government, profit, and non-profit organizations and communities (quadruple helix concept). Overall, this study provides a conceptual framework that enables an understanding of the phenomenon of social entrepreneurship growth and its role in empowering community disabilities. Also, this research also tries to facilitate the stakeholders involved to contribute to the empowerment of community disabilities.
\end{abstract}

Keywords: Conceptual model; Disability communities; Quadruple helix; Social entrepreneurship, Value co-creation

This is an open access article under the CC-BY-NC license.

\section{INTRODUCTION}

Entrepreneurship becomes a new phenomenon in the creation of business opportunities. The positive impact of entrepreneurship activity is the creation of new job opportunities, the increase of society's income, and the increasing of competitiveness. However, the increasingly fierce business competition, making some entrepreneurs ignores social values and humanity. Social problems are one of the main problems that occur in Indonesia. Some of the social problems are unemployment, poverty, and environmental damage. Based on data from the Central Bureau of Statistics (2017), unemployment and poverty in Indonesia are still quite high, the number of unemployed in 2017 reached 5.5 million people, and the number of poor people reached 10.64 percent of the total Indonesia population. Although based on data, there is a decrease in the number of unemployed and poor people every year. However, the decline is slow. One of the causes is an entrepreneurial activity that lacks social usefulness and value for society. During this time, entrepreneurship is only able to create jobs and a two-way relationship (employers and workers). Meanwhile, societies just become the target market or customer object.

Corresponding author 
According to World Economic Forum, a foundation that moves to encourage social entrepreneurship activities states that social entrepreneurs create and lead organizations to generate profits aimed at catalyzing social change in a system through new ideas, products, services, methodologies and change of attitude (World Economic Forum, 2015. This definition explains how social entrepreneurs promote systemic change in their social environment by altering the behavior and understanding or awareness of those around them (Bornstein, D., 2007). Social entrepreneurship is different from the usual or commercial business, with one main character is a concern for the efforts to help the welfare of others rather than self.

Currently, social entrepreneurship has become a new trend in the life of the global community, not least in Indonesia. Social entrepreneurship globally received attention when Muhammad Yunus won the 2006 Nobel Peace Prize for pioneering the development of microcredit and social business (Grameen Bank). The passion for social entrepreneurship in Indonesia began to grow; various activities were organized, including seminars or workshops on social entrepreneurship, the establishment of a social entrepreneurship study center on several campuses, and the establishment of the Indonesian Social Entrepreneurship Association on November 16, 2009. The above phenomenon shows that many people believe that social entrepreneurship is one of the indispensable solutions to solve social problems in Indonesia. Social entrepreneurship emphasizes its businesses by engaging the community and empowering socially incapable people by improving its skills to drive its business to make a profit jointly. However, research on social entrepreneurship still lags far behind its practice (Johnson, S., 2000).

The concept of social entrepreneurship continues to show different things, and there is no clear understanding of how to qualify for social entrepreneurs. Meanwhile, the term social enterprise is used to refer to the activities undertaken by a particular organization or institution. Social enterprises are organizations that pursue social and economic goals with an entrepreneurial spirit. Social companies are typically involved in the delivery of social services and work integration services to disadvantaged groups and communities, both in urban and rural areas. One of community empowerment through social enterprises activity is empowering a community of disability. Based on the Convention on the Right of Persons with Disabilities (CRPD) held in 2007 in New York, the USA, countries in the world have agreed that persons with disabilities are persons with physical, mental, intellectual or sensory limitations causing obstacles in interacting with the environment and difficult to participate fully and effectively ( Central Bureau of Statistics, 2017 ). The emphasis on the meaning of disability in this concept is a long-standing disruption of functions and limited participation in society.

Based on data from LPEM FEB University Of Indonesia (2017), the estimated number of persons with disabilities in Indonesia is 12.15 percent or nearly 30 million people. The prevalence rate of disability in provinces in Indonesia is between 6.41 percent and 18.75 percent, where the three highest prevalence provinces are West Sumatra, East Nusa Tenggara, and South Sulawesi. Meanwhile, people with disabilities participating in the labor market were 51.12 percent. People with disabilities with a minimum elementary education level amounted to 54.26 percent, while those with disabilities who do not pass and never even received elementary education by 45.74 percent. The number of people with disabilities is higher in women with 53.37 percent, while the remaining 46.63 percent are male. 
Many things cause the low percentage of disabled participation in work; one of the factors is the mental of Indonesian society in general which makes the disfigured feel discriminated against early on. Family and education are essential in building the confidence of disabled people to be more active in the labor market. Since 1999, Indonesia has ratified the Convention on Discrimination (in Employment and Occupation) (No.111). Indonesia has also confirmed the UN Convention on the Rights of Persons with Disabilities (UNCRPD) in October 2011. This ratification recognizes that disabled persons are vulnerable to discrimination, particularly in access to education, skills training, and employment. Through community empowerment methods, social entrepreneurship can create many jobs and create multiplier effects to drive the economy and create social welfare, especially for people with disabilities. Community-based social entrepreneurship development is one of the implementations of the form of social entrepreneurship process to empower society economically.

This study aims to analyze the process of social entrepreneurship to empower communities, especially communities with disabilities, conducted by social enterprises. The informal sector is becoming the most desirable field for persons with disabilities. One of the sectors that contribute to the absorption of economic activities for persons with disabilities is entrepreneurship. The rising number of entrepreneurs in Indonesia cannot be separated from the participation of persons with disabilities who work through various forms of the profession. This research is an effort to identify the effectiveness of the social entrepreneurship framework in community empowerment economically. Currently, there is still limited research related to the exploration of the disabilities community; although they have limitations, they have the same opportunities financially with society in general.

\section{LITERATURE REVIEW}

\section{Social Entrepreneurship and Social Enterprises}

The concept of social entrepreneurship has many different perspectives that do not have a clear understanding (Okpara, O. J., and Halkias, D., 2011). In general, the concept of social entrepreneurship refers to the application of entrepreneurial activities based on embedded social goals ( Martin, R.L., and Osberg, S., 2007). Based on previous research, one definition of social entrepreneurship was built based on observations of entrepreneur characteristics ( Dees, J.G., 1998), ( Jones, A.L. et al., 2010). Some of these characteristics can identify opportunities from social problems to create value or find solutions ( Dees, J.G., 1998). It is supported by Okpara, O. J., and Halkias, D., (2011) that social entrepreneurs focus on exploring opportunities to create social value by knowing unmet needs or needs in society, then in the process involves innovation to provide new products or services.

Academically, the concept of social entrepreneurship has been developed in universities ( Nicholls, A., 2006). One of them is an existing university in England, such as the Skoll Center for Social Entrepreneurship. The United States also established centers for social entrepreneurship studies, for example, the Center for the Advancement of Social Entrepreneurship at Duke University. The implementation of social entrepreneurship practices is found in the Ashoka Foundation, a global foundation that specifically seeks social entrepreneurs in different parts of the world to foster and provide funds for drivers of social change. Bill Drayton (founder of the Ashoka 
Foundation) as the initiator of social entrepreneurship confirms that there are two critical points in social entrepreneurship: first, the existence of social innovation that can change the existing system in society; second, the presence of visionary, creative, entrepreneurial, and ethical individuals behind the innovative idea. Research by Hulgard (2010) summarizes the definition of social entrepreneurship more comprehensively: "the creation of a social value that is produced in collaboration with people and organization from the civil society who are engaged in social innovations that usually imply an economic activity". The comprehensive definition provides an understanding that social entrepreneurship consists of four main elements: social value, civil society, innovation, and economic activity.

Based on an organizational level (strategy or mission focused on social impact and innovative approach to achieving the mission), social entrepreneurship can be seen from two elements ( Nicholls, A., 2006): focus on a social mission, which is reflected in the context and output of action according to the value component social; and, the operational process, the approach to action with the 'entrepreneurial' part. The social aspect of the social entrepreneurial organization is reflected in social goals or missions. Focusing on social missions is the same as identifying social needs or new social value creation opportunities. The social purpose of creating social impacts becomes the primary and decisive criterion by looking at the operational context of the business, as well as the resulting output and impact.

Social entrepreneurship is an activity of creating social value innovatively, while social enterprise is an organization that engages in maintaining and creating social value through a business approach (Liebowitz, J., 1999). Social enterprises aim to create innovative business models that can carry out their social mission and sustain their business. The idea raises a big question about 'what exactly is a social value?' And that will be followed by another question about 'how do they create social value?' ( Mulyaningsih.HD. et al., 2014).

The social enterprise as the unit of analysis has emerged significantly as a research phenomenon in terms of practice and theory ( Kurbatov, V. L., et al., 2013). Social enterprises have a role in encouraging social entrepreneurship through the process of community empowerment economically; it must be supported by various stakeholders concerned. Research on social entrepreneurship and social enterprise is far behind compared to practice, although many researchers have been concerned about the issue. Various phenomena related to social entrepreneurship and social enterprise have emerged and are interesting to be studied further. This opens new loopholes in uncovering research in the field of social entrepreneurship and social enterprise.

In developing a conceptual framework, the first step is defining social entrepreneurship in three main syntheses: content, context, and process. Furthermore, the study developed a coherent conceptual framework for covering social entrepreneurship based on the terms: social values, civil society, social innovation and economic activity (Brooks, 2009; Mulgan, G et al., 2007; Kong, E., 2010). In this research, it is proposed the collaboration of various stakeholders involved in quadruple helix actors (academics, business, government, and community). For social enterprises, the need for competition and competitive advantage is needed, especially in the social areas under investigation. Furthermore, the social enterprise must maintain its efforts to defend itself and grow larger in many ways by innovating. In particular, this implies the need for innovation in the 
organization. The conception of goals is a prerequisite for innovation, and every innovation is aimed at solving appropriate problems (Martin \& Orsberg, 2007).

\section{The Concept of Quadruple Helix}

The concept of the quadruple helix has been developed and used by various previous studies. Previous research has added a civil society to the academia, industry, and government that exists today (MacGregor et al., 2010; Maldonado et al., 2009). According to Leydesdorf and Meyer (2006), triple helix model research focuses on the relationship between government, academia, and industry, where the interaction between helices requires dynamic action between them and the respective helical roles will be driven from their contribution to each role (Farinha \& Ferreira, 2011). However, the concept of the quadruple helix has not been recognized more widely than the concept of the triple helix, and a series of additions in this concept still have various conceptions or approaches and perspective differences on some scientists (Meanings HD et al., 2015).

According to Maldonado et al. (2009) considered that civil society organizations occupy strategic positions in public life. Civil society needs to be combined to complete the helix model (MacGregor et al., 2010). Social enterprises are a social entrepreneurial-based organizations that can act as a partner in a network of joint actions. Also, the quadruple helix model proposed by Carayannis and Campbell highlights the importance of the diversity of agents, actors, and organizations ( Carayannis \& Campbell, 2009; 2010). The suggested potential model for increasing the variety of actors in the formation of joint action networks for community empowerment depends on three pillars - by involving social enterprises as an organization that initiates and promotes community empowerment based on social entrepreneurship. This quadruple helix model offers an expansion of the triple helix model that can recognize the importance of various actors in a thriving knowledge economy. The conceptual model proposed in this study identifies the potential for increasing the diversity of actors considered important in the widespread knowledge economy, particularly encouraging the economic potential of the disability community through an entrepreneurial community-based empowerment process.

\section{RESEARCH METHOD}

This research is based on the entrepreneurship-driven phenomenon, which supports government programs to increase the number of entrepreneurs in Indonesia and the community empowerment of disabilities economically. Entrepreneurship contributes significantly to the economy and opens up enough jobs for the community. Social enterprises are a form of social entrepreneurial organization activity as one of the efforts to overcome social problems faced and compete on a broader level. A holistic research approach is used to understand the phenomenon of linkage complexity between all factors and actors ( Damanpour F, 1991; Greenhalgh et al., 2004); Fagerberg et al., 2005; Saunders \&Lewis, 2012).

This research uses qualitative research method with a descriptive and holistic approach, where the approach is not merely a data collection technique but is an empirical approach. Descriptive research is a formulation of the problem that helps researchers reveal or photograph the social situation under study thoroughly, widely and deeply. Thus, qualitative descriptive 
formats are more appropriate when used to examine problems that require in-depth study (Creswell, 2009; Saunders \&Lewis, 2012).

The conceptual framework is one of the approaches in the qualitative method, in which the process of constructing the conceptual framework in this study is based on existing literature and refined through the implementation review on the object of research. A conceptual framework is an interrelated concept that together provides a thorough understanding of a comprehensive phenomenon, in which each concept plays an integral role (Jabareen Y, 2009). A holistic approach is used to generate an integrative conceptual framework for reference. The conceptual model can be used as a basis in the criteria of choosing the right and comprehensive case study.

\section{FINDINGS AND DISCUSSION}

\section{The Role of Social Enterprises in the Empowerment of Disabilities Community}

Disability communities are a diverse group of people, including physical disability, mental disability as well as a combination of physical and mental disabilities. According to the International Labour Office, which is published by the World Health Organization (WHO), there are about one million people in the world who have disabilities. The condition of persons with disabilities may have little impact on the ability to participate in society or even have a major impact, requiring support and assistance from others ( ILO, 2005). People with disabilities face greater difficulties than the general public because they have barriers to accessing public services. Persons with disabilities often lack access to adequate education, health care, and economic activity. Lack of access to transportation, buildings, education, and employment are some examples that hinder people with disabilities.

According to Coleridge, (1993), stated that negative social attitudes of normal people cause people with disabilities not to be given space to contribute their ability to society. There is an unequal distribution of resources, unequal patterns of relationships, and unequal opportunities to participate in everyday life when compared with normal people (Coleridge $P$, 1993). Persons with disabilities are disadvantaged in a social network (Baron, 2000).

Empowerment is the strengthening of communities to participate in decision-making processes that affect their future, strengthening communities to obtain production factors, and strengthening communities to be able to determine their future choices (Sen \& Grown, 1987). Community empowerment activities include increased access to business capital assistance, improved access to human resource development; and, increased access to facilities and infrastructure. The empowerment process has a tendency to emphasize the process of giving or transferring some power, strength or ability to the community to make individuals more empowered (primary empowerment); and highlights the process of stimulating, encouraging, or motivating individuals to have the ability or empowerment to determine their choice of life through a process of dialogue (secondary empowerment).

Empowerment in the context of persons with disabilities is the effort to build, encourage, motivate, and awaken awareness of their potential and assist with protecting as an effort to prevent unhealthy competition. Thus, people with disabilities are expected to develop the potential to be more independent. Empowerment can also be seen as giving disabled people the ability to help themselves and live independently. Solidarity and mutual support are the basis of collective action to improve the current situation of persons with disabilities in society. The empowerment of 
persons with disabilities can also be an effort to fulfill their rights as individuals and citizens so that people with disabilities are integrated into society (Coleridge $\mathrm{P}, 1993$ ).

Community empowerment economically can be conducted through intrapreneurship and entrepreneurship. Empowerment through intrapreneurship is how to prepare workers with disabilities to be accepted in the labor market. Empowerment through entrepreneurship is the education of how people with disabilities can establish an independent business. In reality, companies that employ people with disabilities are still very minimal. Workers are part of the production factor that is very important for the company because it can affect the company's activities. This is because workers are factors of production that can manage other production factors so that companies ultimately can achieve company goals effectively and efficiently, including reducing production costs and increase corporate profits (Ramadani et al., 2017; Draskovic et al., 2017; Bejtkovsky et al., 2018)

Social enterprises are an entrepreneurship-based business organization, which has the goal of not only generating financial benefits but engaging in social missions, community empowerment ( Mulyaningsih et al., 2016; Ramadani et al., 2017; Popov et al., 2018). In general, social enterprises provide support and facilities such as revolving capital assistance, infrastructure development assistance; strengthening and development of business partnerships; and facilitation of business assistance. However, in reality, these activities can not only be conducted by social enterprises because they must be done continuously and involving various parties. The involvement of various stakeholders with their respective roles can maximize community empowerment efforts, especially in disability communities.

\section{Conceptual Model}

Based on the previous discussion, community empowerment in community disabilities requires the involvement of various stakeholders. The involvement of various stakeholders is crucial in increasing potential and encouraging disability communities in economic activities. The concept of a quadruple helix which consists of academic, business, government, and society, is a potential collaboration in helping social problems faced by the disabilities community. Each stakeholder has an essential role in the concept of community empowerment. The conceptual model of this research can be seen in the figure below.

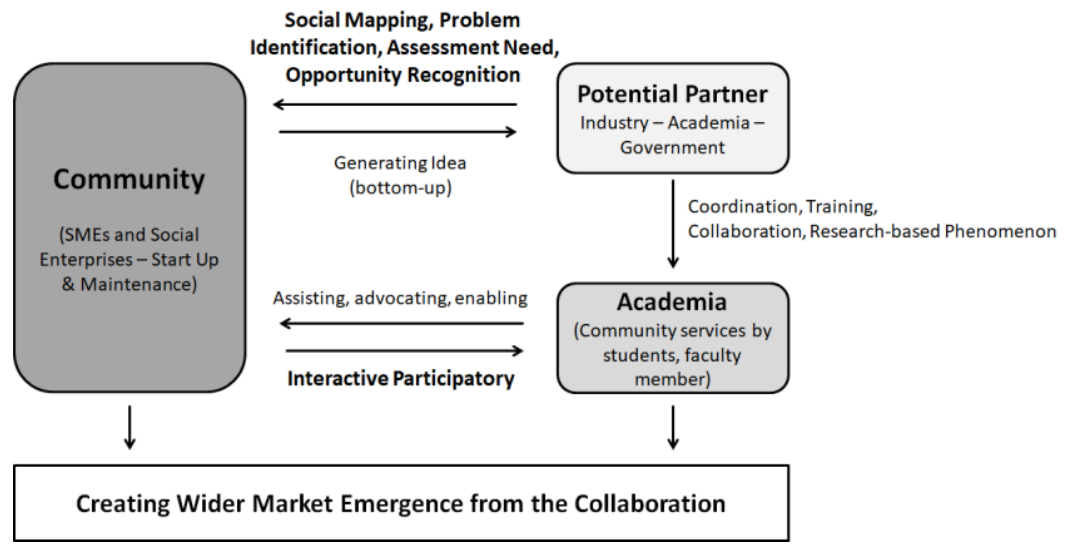

Figure 1. Conceptual Model of Community Development in the Perspective of Quadruple Helix 
This research proposes a conceptual framework model that is developing a model of community development in the perspective of a quadruple helix. Most disability communities face obstacles in various aspects, including social problems where they lack the support system from their social environment. The social environment has not given room to receive and understand people with disabilities. The growth paradigm is that they have physical deficiencies and cannot perform activities like normal people (Coleridge P, 1993, Ramadani et al., 2017). In many countries, children with disabilities are deemed incapable of learning, regardless of the disability experience. Also, they are also often regarded as a bully or obstacles in the learning process. Many people with disabilities can be exemplary by having a spirit with the condition; even the potential of people with disabilities can be better than normal people.

Currently, social enterprises have grown in the socio-economic sector, which lies between markets and countries and is often associated with concepts like the 'third sector' and 'non-profit sector' (Popov et al., 2018). The concept of social enterprise seeks to bridge the non-profit sector or social economy by focusing on new entrepreneurial dynamics for initiatives in pursuit of social goals. The role of social enterprises can be conducted by various parties (Ramadani et al., 2017; Drascovic et al., 2017). The emphasis in this research is the collaboration of stakeholders in the concept of a quadruple helix, where each stakeholder has roles and responsibilities in a comprehensive community empowerment effort, especially empowerment in the disability community. The government has a role in making policies and providing support systems, including adequate facilities to ensure equality for disability communities. Also, government, industry, and academia are potential partners in conducting social mapping, problem identification, assessment need, and opportunity recognition for the community. Academia involvement in the process of community empowerment is also very needed; as a member of knowledgeable communities, academia is expected to provide support in the form of assisting, advocating, and enabling. The active participation of the community is the success indicator of the involvement of various stakeholders in running their respective roles (Drascovic et al., 2017 ; Lacap et al., 2018).

\section{CONCLUSION}

This paper discusses community empowerment based on social entrepreneurship in encouraging economic activity, especially in the disability community. Disability communities still experience discrimination in social and economic environments. However, attention to the disability community has been increasing. Disability communities have potential in a variety of activities, especially the economy, and sometimes their potential exceeds the normal person in general. This research is an initiative in bridging the development process of community disability empowerment in gaining the widest access. Thus, this study proposes a conceptual model of the potential collaboration of various actors in a quadruple helix (academia, business, government, and community), analyze theories and models in the implementation of community empowerment activities based on social entrepreneurship. Social enterprises are one of the organizations that bridge the process of community empowerment with various stakeholders.

One of the most important aspects of community development in disability communities is their need to gain the widest possible access, such as society in general, especially in economic activity. This paper offers a conceptual framework of a multi-stakeholder collaborative process in community empowerment, dedicated to disability communities that take into account their 
specifications. This paper describes community empowerment activities undertaken by social enterprises and the importance of collaboration of various stakeholders, and the roles and responsibilities of each stakeholder. Understanding this conceptual framework will help all stakeholders to focus on their roles and responsibilities that can ultimately drive community participation rates economically. This article offers insight into the understanding of community empowerment models that can help stakeholders understand how it works and how to use it. Also, provide guidelines that the community can use for implementation and when to use it best.

One recommendation for further research is to apply the conceptual model and analyze its impact. Another recommendation is to look at the impact of this conceptual model in different countries (developed and developing), so we can see how each character and its stages. Also, we also recommend applying proposed conceptual models in different communities so that we can see the characteristics and differences of each community. Another suggestion related to this topic is further research to identify which models and strategies demonstrate better performance, combinations with some models that can deliver better results or new models used in community development with broader stakeholder engagement other than in the concept of a quadruple helix.

\section{REFERENCES}

Barnes, C., and Mercer, G., 2010. Exploring Disability. Polity Press, Cambridge.

Baron, R. A., 2000. Social capital. John Wiley \& Sons, Ltd.

Bejtkovsky J., Rozsa Z., Mulyaningsih D.H. 2018. A Phenomenon of Digitalization and ERecruitment in Business Environment. Polish Journal of Management Studies. Vol. 18. No.1

Bornstein, D., 2007. How to change the world: Social entrepreneurs and the power of new ideas. Oxford University Press.

Brooks, C. A., 2009. Social Entrepreneurship: A Modern Approach to Social Value Creation. Pearson Prentice Hall, Pearson Education, Inc, New Jersey.

Carayannis, E. G., and Campbell, D. F., 2009. 'Mode 3'and'Quadruple Helix': toward a 21stcentury fractal innovation ecosystem. International journal of technology management, 46(3-4), p. 201-234.

Carayannis, E. G., and Campbell, D. F., 2010. Triple Helix, Quadruple Helix, and Quintuple Helix and how do knowledge, innovation and the environment relate to each other? A proposed framework for a transdisciplinary analysis of sustainable development and social ecology. International Journal of Social Ecology and Sustainable Development 1(1), p. 41-69.

Coleridge, P., 1993. Disability, liberation, and development. Oxfam Central Bureau of Statistics., Social dan Kependudukan. Retrieved from https://www.bps.go.id/index.php, accessed November 27, 2017.

Central Bureau of Statistics, BPS Dukung Hak Penyandang Disabilities. Badan Pusat Statistik, Retrieved from https://www.bps.go.id/index.php/kegiatanLain/91, accessed November 27, 2017.

Creswell, J.W. ( 2009). Research Design : Qualitative, Quantitative and Mixed Methods Approaches. Sage Publications Inc. London

Damanpour, F., 1991. Organizational innovation: A meta-analysis of effects of determinants and moderators. Academy of management journal, 34(3), p. 555-590.

Dees, J. G., 1998. Enterprising Non-Profits. Harvard Business Review, Vol. 76, No.1 p. 55-66. 
Draskovic, M ., Delibasic, M., Ivic, M., Oksana, C. 2017. Preference of Institutional Changes in Social and Economic Development. Journal of International Studies. Vol. 10. No. 2.

Fagerberg, J., Mowery, D. C., and Nelson, R. R. (Eds.)., 2005. The Oxford handbook of innovation. Oxford university press.

Farinha, L., and Ferreira, J. J., 2011. Triangulation of the triple helix: a conceptual framework. University of Beira Interior, 25.

Greenhalgh, T., Robert, G., Macfarlane, F., Bate, P., and Kyriakidou, O., 2004. Diffusion of innovations in service organizations: systematic review and recommendations. The Milbank Quarterly, 82(4), p. 581-629.

Hulgård, L., 2010. Discourses of social entrepreneurship-Variations of the same theme. EMES European Research Network Johnson, S.,2000. Literature reviews on social entrepreneurship. Canadian Centre for Social Entrepreneurship, p. 16- 23.

International Labour Office, ILO and Disability Inclusion. ILO Publication, September 2005.

Jabareen, Y., 2009. Building a conceptual framework: philosophy, definitions, and procedure. International Journal of qualitative methods, 8(4), p. 49-62.

Jones, A. L., Warner, B., and Kiser, P. M., 2010. Social entrepreneurship. Planning for Higher Education, 38(4) p. 44.

Kurbatov, V. L., Glagolev, S. N., and Fursova, S. A., 2013. The epistemological basis of innovations. World Applied Sciences Journal, 24(11), p. 1510-1518.

Kong, E., 2010. Innovation Process in Social Enterprises: an IC Perspective. Journal of Intellectual Capital, Vol. 11, No.2, p. 158-178.

Lacap, Jean PG., HD. Mulyaningsih., Veland, R. 2018. The Mediating Effects of Social Entrepreneurial Antecedents on the Relationship between Prior Experience and Social Entrepreneurial Intent: The Case of Filipino and Indonesian University Students. Journal of Science and Technology Policy Management. Vol. 9. Issue 3. Pp 329-346

Leydesdorff, L., and Meyer, M., 2006. Triple Helix indicators of knowledge-based innovation systems: Introduction to the special issue. Research Policy, No. 35, Vol. 10, pp. 1441-1449.

LPEM FEB UI., 2017. Laporan Akhir Memetakan Penyandang Dsabilitas (PD) di Pasar Tenaga Kerja Indonesia. Organisasi Perburuhan Internasional.

Liebowitz, J., 1999. Knowledge management handbook. CRC Press, USA.

Martin, R.L., and Osberg, S., 2007. Social Entrepreneurship: The case for definition. Stanford Social Innovation Review Spring: 29-39.

Mulyaningsih, H. D., Yudoko, G., and Rudito, B., 2014. Initial Conceptual Model of KnowledgeBased Social Innovation. World Applied Sciences Journal, Vol. 30 .p. 256-262.

Mulyaningsih, H. D., 2015. Enhancing innovation in quadruple helix perspective: The case of the business incubators in Indonesia. International Business Management, 9(4), p. 367-371.

Mulyaningsih, H.D., Gatot Yudoko and Bambang Rudito (2016). Knowledge-based Social Innovation in Social Enterprise: A conceptual framework. Advance Science Letter Vol. 22, No. 5/6 .May/June - 2016

Mulgan, G., Tucker, S., Ali, R., and Sanders, B., 2007. Social innovation: what it is, why it matters and how it can be accelerated — Skoll Centre for Social Entrepreneurship. 
MacGregor, S. P., Marques-Gou, P., and Simon-Villar, A., 2010. Gauging readiness for the quadruple helix: a study of 16 European organizations. Journal of the Knowledge Economy, 1(3) p. 173-190.

Maldonado, V., Lobera, J., and Escrigas, C., 2009. The role of higher education in a new quadruple helix context. Triple Helix, 7, p. 17-19.

Nicholls, A., 2006. Social Entrepreneurship. In: Carter, Sara and Evans-Jones, Dylan, (eds.) Enterprise and Small Business: Principles, Practice and Policy. Financial Times Prentice Hall.

Okpara, O. J., and Halkias, D., 2011. Social Entrepreneurship: An Overview of Its Theoretical Evolution and Proposed Research Model. International Journal Social Entrepreneurship and Innovation, Vol. 1, No. 1.

Popov, Evgeny V., Anna, YV and Ksenia, MK. 2018. Formal Institutional Environment Influence on Social Entrepreneurship in Developed Country. Montenegrin Journal of Economics. Vol.14. No. 4. Page 045-156

Ramadani V., Leo-Paul D., Shqipe Gerguri-Rashiti., Vanessa R., 2017. Social Entrepreneurship and Management in Islamic Context. Springer, p. 143-158

Saunders, Mark and Philip Lewis. (2012). Doing Research in Business and Management: An essential guide to planning your project. Prentice-Hall - Pearson

Sen, G., and Grown, C., 1987. Development alternatives with women for a new era. London: Earthscan.

World Health Organization, 2011. World Report on Disability. Geneva: WHO.

World Economic Forum., 2015. Schwab Foundation for Social Entrepreneurship Annual Report 2014-2015. World Economic Forum, Switzerland. 